The Economic and Social Review, Vol. 37, No. 2, Summer/Autumn, 2006, pp. 263-294

\title{
Ireland in EMU: More Shocks, Less Insulation?**
}

\author{
PATRICK HONOHAN \\ The World Bank and CEPR
}

and

\author{
ANTHONY J. LEDDIN \\ University of Limerick
}

\begin{abstract}
Despite anchoring the Irish monetary system to a common zone-wide exchange rate and interest rate, EMU has triggered sizeable exchange rate and especially interest rate shocks to the Irish economy (albeit not appreciably greater than those experienced under previous exchange rate regimes). Interest rate movements have deviated widely from what a standard Taylor monetary policy rule would have counselled - though here again the deviations have been no worse in this regard than those of the previous regime. The most important shock has been associated with the large and sustained initial fall in nominal interest rates as EMU began. Through mechanisms which we formally model, the interest rate fall has had a lasting effect on property prices, construction activity and the capacity of the labour market to absorb sizeable net immigration, despite a sharp deterioration in wage competitiveness since 2002. As the long drawn-out impact of this shock subsides, the failure of the wage-bargaining system promptly to claw back the loss of competitiveness resulting from exogenous exchange rate movements is increasingly likely to show up in weaker aggregate employment performance.
\end{abstract}

\section{INTRODUCTION}

$\mathrm{H}^{3}$ as Ireland's entry into EMU in 1999 tended to destabilise the economy? It could have done so in two ways, first by increasing the scale and frequency of exogenous shocks hitting the economy, and second by suppressing some shock absorbers in the system, placing more pressure elsewhere. In both

\footnotetext{
*An earlier version was presented at the Conference on Macroeconomic Perspectives in Honour of Brendan M. Walsh, held at University College Dublin on 7 October, 2005. We are grateful to John Fitz Gerald, Philip Lane, Peter Neary, Rodney Thom, Jonathan Wright, and two referees for their suggestions. Thanks also to Adele Bergin for making the ESRI database available to us. The views expressed are personal. phonohan@eircom.net; anthony.leddin@ul.ie
} 
cases, the primary transmission channels are exchange rate and interest rate movements. Prior to EMU entry, the nominal interest rate in Ireland was endogenous in the national economy and subject to national policy influence as indeed was the nominal exchange rate to some extent. As such, they could in principle represent a fast-adjusting part of the system's adaptive capacity. Now, in EMU these key variables are exogenous and cannot be relied upon as a lubricant, to move in a stabilising manner when the Irish economy is hit by idiosyncratic shocks. Not only that: there is also the potential for exogenous movements in interest rates and in the effective exchange rate to operate as destabilising forces.

This concern is no longer an abstract one. Indeed the first years of the new system, marked by extremely rapid real economic growth, and by a decline in unemployment to record lows, also saw a sharp procyclical decline in real interest rates and in the effective exchange rate index. Shocks which are not absorbed by insulating interest rate and exchange rate movements, or which are the consequences of destabilising movements in these rates, may show up in other prices or in quantities. ${ }^{1}$ The major elements here include real wage rates, unemployment and migration, property prices and construction activity, and - an element largely ignored in this paper - fiscal aggregates. Of these, migration and property prices tend to be neglected in the international macroadjustment literature, but they have clearly been important in Ireland (cf Fitz Gerald, 2001, Leddin and Walsh, 2003). Of course, there are channels through which EMU membership may have had a stabilising effect. Expectations of exchange rate movements and medium term inflation previously a source of instability ${ }^{2}$ - have become insensitive to domestic developments.

The paper looks both at whether the exogenous exchange rate and interest rate have had the effect of increasing the scale and frequency of exogenous shocks hitting the Irish economy, and at how key variables in the remainder of the economy - the share of construction in total employment, house prices, inward migration and labour competitiveness - have responded to the largest of these shocks. We find that exogenous exchange rate shocks to the Irish economy are sizeable, but not much more so than under previous regimes. We confirm that interest rates have not moved in line with a stabilising monetary policy for Ireland - though again the deviations have been no worse in this

\footnotetext{
1Although, as pointed out by Flood and Rose (1995) there has been little empirical evidence that fixing exchange rates increases the volatility of real variables.

2 For two decades pre-EMU such expectations were on average for a higher-than-realised depreciation and surged in response to certain configurations of domestic and international shocks, resulting in high ex post international interest rate differentials (Honohan, 1993; Honohan and Conroy, 1994; Walsh, 1993).
} 
regard than those of the previous regime. The most important shock has been associated with the large and sustained fall in nominal interest rates. This has been reflected in property prices, construction activity and the capacity of the labour market to absorb sizeable net immigration, despite a sharp deterioration in wage competitiveness since 2002.

Although the paper touches on a rather wide range of Irish macroeconomic topics, we were struck by the fact that in each area, Brendan Walsh's contributions represent a central part of the literature. In so many instances his early contributions pioneered the application of modern economic analysis to Irish topics, as for example, on econometric modelling (Walsh, 1970); migration (Walsh, 1974); exchange rate regimes (Walsh, 1984) and so on. We welcome the opportunity to add a few bricks to an edifice that Brendan has done so much to build over the past four decades.

Section II contains a brief general overview of Ireland's experience to date in EMU, highlighting the key exogenous shocks - the initial fall in interest rates, the two-way swing in the external value of the euro, and the international slow-down following the bursting of the technology bubble - and the response of the Irish economy, with sustained migration, continued house price inflation and only a modest dip in real output growth. Section III assesses the impact of the change in exchange rate regime on the nature and magnitude of exogenous shocks, looking separately at exchange rate and interest rate movements. The next two sections consider the endogenous (market) response of other key domestic variables to these and other shocks. Using a simple theoretical model of short-run dynamics, Section IV illustrates the potential role of migration and the property market in amplifying and prolonging the impact of shocks such as the initial interest rate decline. Section V proceeds to look at the empirical evidence for these two price and quantity adjustments in two key markets: those for residential property and for labour documenting in particular the continuity in the relation between cross-channel unemployment differences and migration and focusing on the evolution of labour competitiveness - where we find that wage determination has not been a stabilising force either. Section VI contains concluding remarks.

\section{OVERVIEW OF IRELAND'S EXPERIENCE IN EMU}

\subsection{The Regime Change}

Following a period of controlled floating within the very wide ERM bands (1993 to 1998), Ireland dissolved its independent currency in the single euro currency of the multi-country European Monetary Union in January 1999. Thus at the time of writing, Ireland has had no independent currency for over 
seven years, or about half as long as the lifetime of the narrow-band ERM (1979-1992). This is a period sufficiently long to begin to provide some information about the magnitude of shocks and the economy's reaction to them.

In terms of the macroeconomic policy environment, abandonment of an independent currency entails the removal of two policy instruments, the nominal interest rate and the exchange rate, both of which could be used to offset shocks. It should, however, be borne in mind that both variables could be subject to suboptimal policy, whether because of technical failings or because of inherent problems of time inconsistency.

The particular choice of alternative currency also matters: if the adopted currency proves stable against the main trading partners, then shocks induced by third-country exchange rate movements will be minimised. In the case of the euro, all exchange rate shocks are clearly reduced against other countries using the euro and those adopting a fixed peg against the euro. However, much of Ireland's trade and financial affairs are with countries that have not adopted or pegged to the euro, most notably the UK, the US (together with countries pegged de facto with the US dollar including up to 2005 China - now Ireland's third largest non-EU trading partner) and Japan.

The preconditions for Ireland's adoption of this regime were not unambiguously favourable. While the macroeconomic situation at the outset was quite good, with unemployment falling, the public finances in surplus and cost-competitiveness conditions favourable, ${ }^{3}$ the structural pattern of trading and investment relations was much less so, with only 19 per cent of merchandise imports and 42 per cent of exports coming from initial EMU members in $1998.4^{4}$ A clear and crucial initial impact, making itself felt before the exchange rates were irrevocably locked, was the sharp once-and-for-all drop in nominal interest rates. A clear benefit to the economy in the long term, this has had a decisive medium-term effect on subsequent macroeconomic developments, not all of it favourable.

\subsection{World Macroeconomic Changes and Ireland's Response, 1999-2004}

At first sight, and in terms of the average major macroeconomic indicators, Ireland's experience in EMU has been an unalloyed success: real GNP growth has averaged 5.7 per cent per annum, average unemployment was 4.4 per

${ }^{3}$ So favourable, indeed, that a small - and perhaps inadequate - upward revision in the ERM central rate had been engineered in the months preceding EMU's start.

${ }^{4}$ The first six years of EMU showed a small decline in this percentage for exports, and only a modest increase to 21 per cent for imports. Instead, the share of the US in Ireland's exports continued to expand and that of the UK to decline. 
cent, the current account balance of payments deficit has averaged less than 1 per cent of GDP per annum and even inflation - clearly the least successful area of the four - can be considered moderate, with the CPI growth coming in at 3.7 per cent per annum on average.

Admittedly, this average data tends to gloss over the activity slowdown from the heady growth rates and falling unemployment of 1999-2000 - which may be considered the last two years of the Celtic Tiger (Leddin and Walsh, 2003) - to the more modest, but still respectable, output and employment achievements of 2001-4. 5 The growth slowdown can be related to the series of shocks, external and internal, which hit the economy from mid-2000. Among the shocks were the peaking of the dot.com bubble, followed by the US recession and reduced growth in most EU markets, the aftermath of the 9/11 events and the run-up in commodity prices, especially petroleum; an additional, more local, factor was the foot-and-mouth disease outbreak in 2001 with consequences for agriculture and tourism. Annual inflation too, displayed a cyclical pattern, surging to a high of 5.6 per cent in 2000 , fuelled by the rise of the US dollar and sterling against the euro, before falling to about 2 per cent by $2004 .^{6}$

This mild nature of the slowdown and the subsequent speedy recovery albeit not to "Tiger" levels - seems to suggest that one of the main anticipated costs of EMU entry, the fear of "prolonged recession" and the inability to adjust to asymmetric shocks, were not entirely justified. The interesting question, however, is whether the recovery was due to the efficient working of internal policy or market mechanisms or rather to fortuitous external or domestic factors (Leddin, 2004)?

This paper will not attempt a detailed discussion of countercyclical fiscal policy, but it would clearly be hard to argue that fiscal policy was actively stabilising. Although loss of the nominal instruments is generally held to create a need for heavier reliance on countercyclical fiscal policy, this lesson does not seem to have been put into effect in Ireland so far. Irish fiscal policy has been largely procyclical during the EMU years, as the government has tended to expand spending in line with revenue during the boom years and

\footnotetext{
5Even in 2002, real GNP growth was as high as 2.7 per cent and by 2003 it had recovered to 5.1 per cent before slowing somewhat to 4.0 per cent in 2004, still close to likely long-term potential growth. However, unemployment started rising for the first time in a decade. Interpretation of the macroeconomic aggregates is complicated by some sharp revisions in these annual growth rates between successive issues of National Income and Expenditure, and of course there is the continuing difficulty of interpreting the level and especially the annual changes of net factor income. Data on trends over 2-3 years may be more stable and reliable.

${ }^{6}$ The currency movements had a larger effect on Ireland than on any other EMU country, because of Ireland's relatively close trade and investment links with the US and UK (Honohan and Lane, $2003 ; 2004)$.
} 
curtail spending during the downturn. Indeed, with the reversal of the dollar and other adverse shocks, Ireland finds itself with less fiscal leeway than if it had held a tight belt in the over-heating period 1999-2000.

\section{INTEREST AND EXCHANGE RATE SHOCKS: HAVE THEY INCREASED IN THE NEW REGIME?}

Prior to EMU entry, the major predicted change was a decline in the level and volatility of real interest rates and the danger of an increase in the tradeweighted exchange rate - at least relative to other available exchange rate regimes (Baker et al., 1996). In this section we show that exchange rate volatility has not clearly increased but that, though nominal interest rate volatility has fallen, the interest rate has not proved to be a stabilising force.

\subsection{Third Country Exchange Rate Movements}

Use of the euro stabilises Ireland's nominal exchange rate but only against partner countries that make up a minority of trade. Given that the euro's exchange rate against third countries is negligibly affected by Irish conditions, the first question is whether this has resulted in a more or less volatile tradeweighted nominal exchange rate in practice and whether it has been associated with a more or less appreciated nominal exchange rate on average. (Here we are taking the nominal exchange rate movements as the shock; the endogenous response of wages is discussed in Section V).

Figure 1 displays a long time series of the nominal effective (tradeweighted) exchange rate index (NEER), from which it is evident from that this slipped to record low levels during the run-up to, and the first two years of EMU. Since 2002, however, it has recovered sharply to reach levels last recorded in 1997. Overall, the new exchange rate regime has delivered in nominal terms a weaker exchange rate on average (index of 62.0) than previous regimes (ERM narrow band: 67.4; ERM wide band: 66.5). (The opposite is true of the real exchange rate, as will become evident below).

The evolution of volatility can be measured in various ways. We discuss two representative measures of the volatility of the nominal trade-weighted exchange rate index: standard deviations of the quarterly level and of the change (first difference) of the index. Figure 2 plots a twelve-quarter moving standard deviation of each and illustrates the fact that there have been several waves of heightened volatility over the years.

Measured in terms of standard deviation of levels, there have been two surges in Irish nominal trade-weighted exchange rate volatility during EMU and, as shown in the Figure, these were as high as anything experienced for 
Figure 1: Nominal Effective Exchange Rate for Ireland 1979-2004

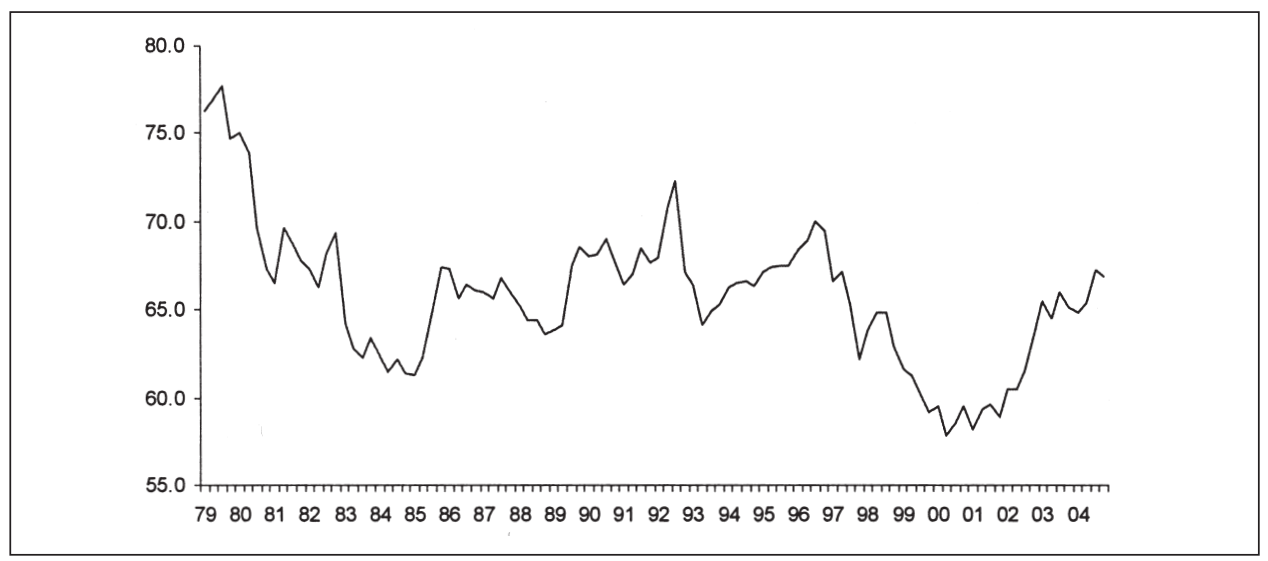

Source: Bank of England (average of the last month of each quarter; to mid-2002); Central Bank of Ireland (trade-weighted competitiveness index - nominal; since mid2002).

almost a quarter century. Measured separately for the three regimes, the narrow band period proves to have the highest standard deviation at 4.1 per cent - reflecting the many realignments - the wide band period has the lowest at 2.3, with EMU so far intermediate at 3.2.

Measured in terms of changes, volatility during EMU has been lower than at most periods in the past. This standard deviation over the EMU period comes out at 1.2 per cent, as compared with 1.3 for the wide-band ERM period and 1.7 for the narrow band (1.4 if the realignments are removed - see below). However, for the other small EMU countries, the reduction in NEER volatility following EMU entry has been much more striking. ${ }^{7}$ This contrast reflects the greater importance of the continued volatility of the euro against sterling and the US dollar - in the latter case the volatility has increased relative to the Irish pound/US dollar rate in the floating period.

Modelling the evolution of the exchange rate as a random walk with timevarying variance (a GARCH model), with dummies in the variance process model for different regimes, suggests that, while variance may have been somewhat higher in the ERM, it is not significantly lower in the EMU period. Not surprisingly, the fit of any such equation is very poor, and even the ERM

7Indeed, for the other small EMU countries: Austria, Belgium, Finland, Greece, Netherlands and Portugal, using the moving 12-quarter standard deviation of (log-)changes as the benchmark, the most recent volatility (to end-2004) is at or close to (less than 44 per cent above) the minimum observed 1981-2004, whereas for Ireland the latest observation is at more than 130 per cent above the minimum. 
Figure 2: Volatility of Nominal Trade-Weighted Exchange Rate

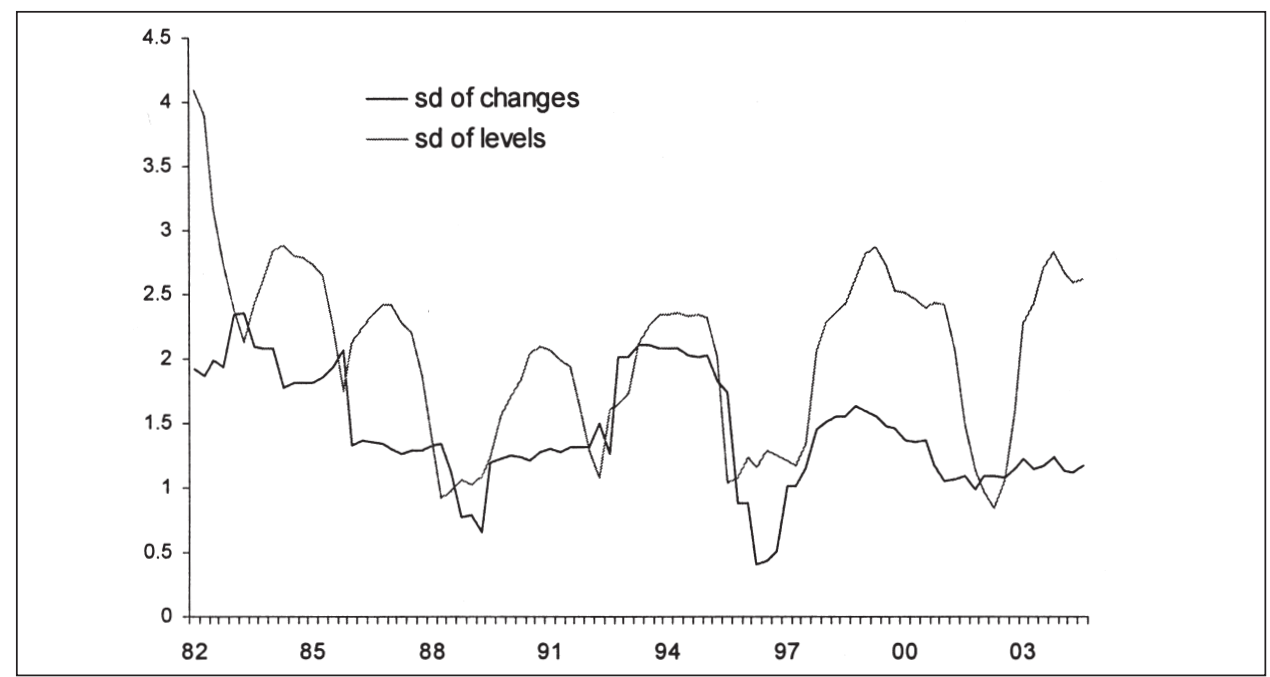

Source: Authors' calculations based on the data of Figure 1.

dummy in the variance equation is not significant even at the 10 per cent level (details shown in the Working Paper version, i.e., Honohan and Leddin, 2005).

Overall, this evidence suggests that high frequency nominal exchange rate volatility has not been higher in EMU (and might even have been somewhat lower). An important additional consideration must be borne in mind. Some of the volatility in pre-EMU times reflects realignments 8 in which the exchange rate was consciously adjusted in a stabilising way. These movements cannot be considered as shocks, but rather as corrective adjustments. So some of the volatility in changes in the ERM is "good" volatility. Indeed, removing the exchange rate changes in the quarters of the three largest realignments for Ireland (March 1983, August 1986 and January 1993) dramatically alters this picture and removes most of the apparent reduction in volatility since EMU began (Honohan and Leddin, 2005). We look at this in more detail below in the discussion of competitiveness.

On balance, then, the data do not point to an improvement as between EMU and previous regimes in regard to exchange rate volatility. This is despite the elimination of bilateral exchange rate changes with all the EMU

\footnotetext{
${ }^{8} \mathrm{Also}$ related to realignments is the fact that the change in exchange rate is negatively skewed $(-0.68)$ in the full period, but not in the EMU period, when skewness is close to zero $(+0.06)$. The skewness in the ERM period presumably reflects the negative jumps at times of realignment. These tend to increase measured variance in the quarterly data, whereas they are absent from EMU, and are likely to be the main reason why variance increases in EMU when measured in levels but not when measured in changes.
} 
members, and despite the expectation of some that exchange rate volatility would decline in net terms. Ireland certainly did not benefit from the sizeable reduction in exchange rate volatility experienced by other EMU members with the arrival of the new regime. On the other hand, it is hard to point to evidence of a major increase in volatility emanating from this source.

\subsection{Interest Rate Levels and Dynamics: Have they Become Less Stabilising?}

Over the period 1999-2004, the average real interest rate in Ireland was -0.9 per cent. Adding to the effect of the sharp decline in nominal interest rates here was the rise in inflation during 1999-2002. Spurring spending, as it did, especially in the construction sector, the fall in nominal rates itself likely contributed to inflation. The experience dramatically illustrates how the adoption of an exogenous nominal interest rate not only removed the potential for this instrument to be used as a countercyclical tool, but also induced a procyclical element because of the fact that, absent a policy response, a rise in inflation automatically generates a fall in real interest rates.

Now that nominal interest rate movements are externally determined, movements in them represent shocks to the system; but have they become more stabilising or more destabilising on average? This question can be divided in two ${ }^{9}$ : First, how close at each date have actual interest rates been to those that would have been adopted by an optimising autonomous monetary policy (the 'levels' question)? Second, has the loss of policy independence led to interest rates being less responsive to inflation and output movements (the 'slope" question)?

The widely-used Taylor rule provides a framework to answer both questions, though it is used in different ways. The Taylor rule is a simple formula setting the nominal short-term interest rate as a linear function of inflation rate and the output gap. ${ }^{10}$

$$
i_{i}=\alpha+\beta\left(\pi_{i}-\pi^{*}\right)+\gamma\left(y_{i}-y^{*}\right)
$$

When inflation exceeds its target value, the interest rate is increased; if the output gap is negative, it is reduced. In the literature, $\pi_{t}$ and $y_{t}$ are either assumed to be the current values, or the authorities' projected future values,

\footnotetext{
${ }^{9} \mathrm{~A}$ third relevant question is whether the volatility of real or nominal interest rates has declined. Here the empirical answer is clear: there has been a decline in nominal interest rate volatility in the EMU period. Real interest rate volatility was, however, lowest in the floating rate period 1994-1998.

${ }^{10}$ See Adalid et al. (2005) (for the Euro area), Dupor and Conley (2004) (for the US) and Kuttner (2004) as examples of the many recent attempts to compare actual interest rate movements to Taylor rule predictions.
} 
for actual inflation and the output gap. In addition, there may be smoothing, with the authorities preferring not to jump immediately to the interest rate indicated by the equation.

The Taylor rule does not necessarily define a true optimal interest rate: it neglects, for example, the fact that the authorities will often hike interest rates to defend a fixed-but-adjustable exchange rate peg. It is best thought of as a useful benchmark summarising the combined demands of output and inflation stabilisation on the monetary authorities. Using the formula to deduce the benchmark requires several practical decisions. First we need to know the parameter values; second, we need to know what data is available to the authorities regarding current and projected inflation and output gap, and whether smoothing is carried out (cf Faust et al., 2001 who also argue that Ireland's interest rates were too low in 1999-2000). There is also the issue of whether producer or consumer prices are more relevant.

Figure 3: Nominal Interest Rates: Actual and Warranted by Taylor Rule

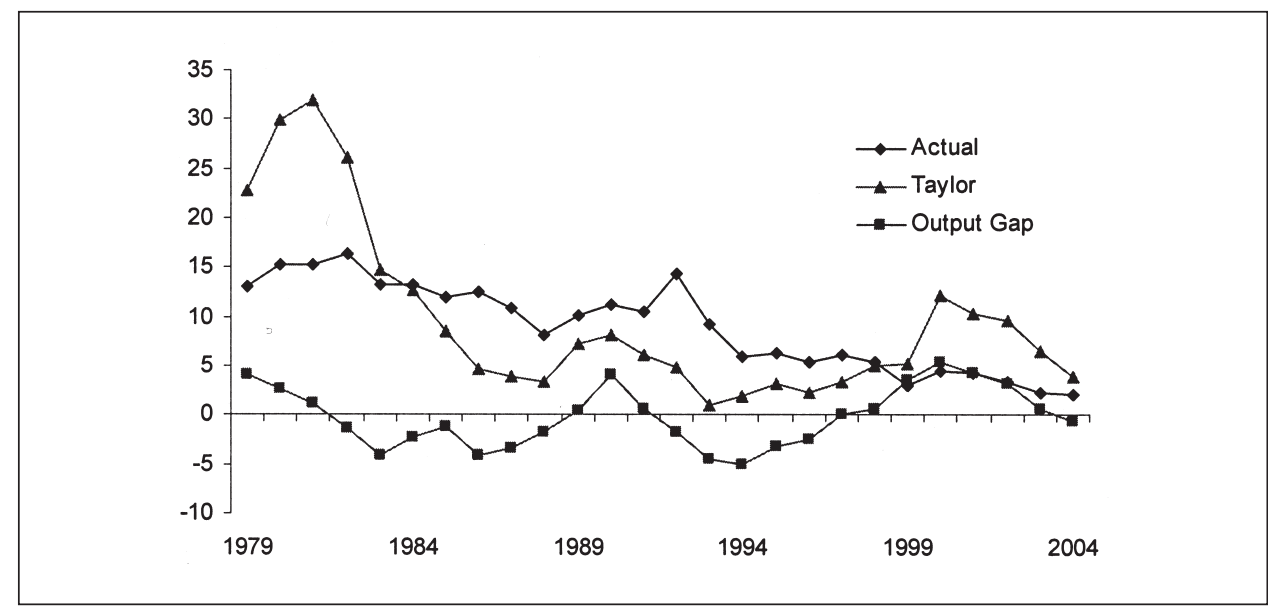

Based on short-term interest rate and output gap series from OECD Economic Outlook 77, June 2005; using parameters $\alpha=4 ; \beta=1.5 ; \gamma=0.5$.

To answer the 'levels' question, we assume that optimal policy corresponds to the Taylor rule with standard parameters. Using this formula, we calculate a normative time series for the nominal interest rate that should prevail at each moment (conditional on the actual inflation and output gap), and compare this with actual interest rates. ${ }^{11}$ Figure 3 shows an interest rate

11The calculations do not pretend to represent for the EMU period the interest rates that would have prevailed had monetary independence been retained. 
series computed using contemporaneous values of CPI inflation and the OECD output gap, Taylor's original parameter values for $\beta$ and $\gamma$, and a constant term set to ensure that the mean value of the normative and actual series over the sample period are equal. The main features are that the Taylor interest rate is much higher than actual before 1984; it then dips below the actual and remains there until 1998. In the EMU period the Taylor rule generates much higher interest rates for Ireland than were actually observed. This long swing, interest rates too low before 1983, too high between then and the EMU, and too low since is neither quantitatively negligible, nor highly sensitive to the assumed parameters of the Taylor rule. The actual and Taylor plots cross at just two points, which thus define three interesting subintervals. The swing in the difference between actual and Taylor values is from an average of minus 1,254 basis points before 1979-1982; plus 430 basis points 1983-97; and minus 400 basis points 1998-2004. (Experiments with a range of alternative standard parameter values for $\beta$ and $\gamma$ that have been proposed in the literature reveal that the qualitative pattern of differences between normative and actual interest rates is the same for a wide range of parameter values; see Table 1). ${ }^{12}$

Figure 3 suggests two complementary conclusions. First, by this reckoning nominal interest rates in EMU have been far too low for Ireland, allowing inflation to surge despite strong output performance. But the second conclusion suggested by Figure 3 is that nominal interest rates missed the mark by at least as wide a margin in the earlier periods also. ${ }^{13}$ Was monetary policy inappropriate then also, albeit in the opposite direction, with interest rates too high during the later part of the ERM period? Excess returns against the anchor currency of that adjustable peg exchange rate regime averaged over 2 percent per annum for two decades, surging when the exchange rate peg was being protected against short-term realignment speculation, and remaining high in calmer times also (Honohan and Conroy, 1994). Real interest rates were much higher too, as illustrated in Figure 4.

Turning to the 'slope' question, instead of simply comparing a time series of normative interest rates with actual, we now examine the short-run correlation of Irish interest rates with inflation and the output gap.

\footnotetext{
12In Honohan and Leddin (2005), we show that Ireland has the distinction of a higher variance in the gap between Taylor rule and actual interest rate than any of the other twelve small countries for which the same data is available, other than Greece. Furthermore, Irish interest rates have averaged further below the Taylor rule value than in any other of these countries since the EMU began.

${ }^{13}$ This statement hinges on the value of the intercept $\alpha$, assumed to be 4 per cent, a value which results in the average gap between Taylor and actual of close to zero. Regardless of the exact value of the intercept we may say that either interest rates were too high before, or too low, since EMU began, or both.
} 
Table 1: Taylor Rule Less Actual Short-Term Interest Rate, Various Periods, Ireland

\begin{tabular}{lllccc}
\hline \hline Parameters as used by: & \multicolumn{1}{c}{$\beta$} & $\gamma$ & $1979-82$ & $1983-97$ & $1998-2004$ \\
\hline Taylor (1993) & 1.5 & 0.5 & -12.54 & 4.30 & -4.00 \\
Honohan-Lane (2003) & 1.5 & 0.125 & -12.25 & 3.57 & -3.08 \\
Fed St Louis (2002) & 1.248 & 0.853 & -8.64 & 5.43 & -4.47 \\
Fed St Louis (2002) & 1.846 & 1.073 & -18.74 & 4.79 & -5.93 \\
\hline \hline
\end{tabular}

Quarterly data from the sources used for Figure 3. The target long-term nominal interest rate $\alpha$ is set at 4 .

Specifically, we assess whether actual Irish interest rates in either ERM, floating or EMU periods can be modelled as a Taylor-type function of inflation and output, albeit with nonstandard parameters. This provides an alternative perspective on the degree to which Irish interest rate movements might still have been somewhat countercyclical. If the estimated coefficient on inflation is greater than unity, real interest rates will have acted in a stabilising manner with regard to inflation (subject to the output gap). But the exogenous nominal interest rate generated for Ireland by EMU membership could have induced a destabilising or procyclical real interest rate dynamic unless Irish inflation was sufficiently closely correlated with that in the rest of the EMU zone.

Some simple regression estimates of a Taylor-type equation are presented in Table 2.14 While crisp and robust results do not emerge, the estimates provide little indication that interest rate movements in Ireland have responded to inflation and output gaps in a manner consistent with a stabilising monetary policy.

When the equation is estimated over the whole period since the ERM crisis of 1992-3, neither inflation nor the output gap is significant (Regression 2).15 If a second order autoregressive process is added, some significance is obtained

\footnotetext{
${ }^{14} \mathrm{~A}$ technical caveat must be entered in regard to these measures: standard tests cannot reject the existence of a unit root in the nominal interest rate. If a quadratic deterministic trend is assumed, however, a cointegrating vector linking the three main variables: the interest rate, inflation rate and output gap is found (Johansen test rejects the alternative of no cointegration). Given the lack of power of unit root tests on short samples, as well as a relatively strong theoretical presumption that, even if nominal interest rates are non-stationary, they could likely be cointegrated with inflation if real interest rates are stationary, it seems acceptable to report levels regressions as in Table 2.

15Regression 1 in Table 2 shows that, in the narrow band ERM period, before the crisis of 1992-3, inflation was significant, with an estimated long-term adjustment coefficient $\beta / \alpha$ of 0.4 . But for this period, defense of exchange rate peg was an important influence on interest rate policy. Indeed, in the narrow-band period there was a positive correlation between real exchange rate appreciation and the level of the real interest rate - a correlation which no longer prevails.
} 
Table 2: Fitting a Taylor Model to Irish Interest Rate Data Quarterly 1980-2004 Dependent Variable is Level of Short-Term Nominal Interest Rate

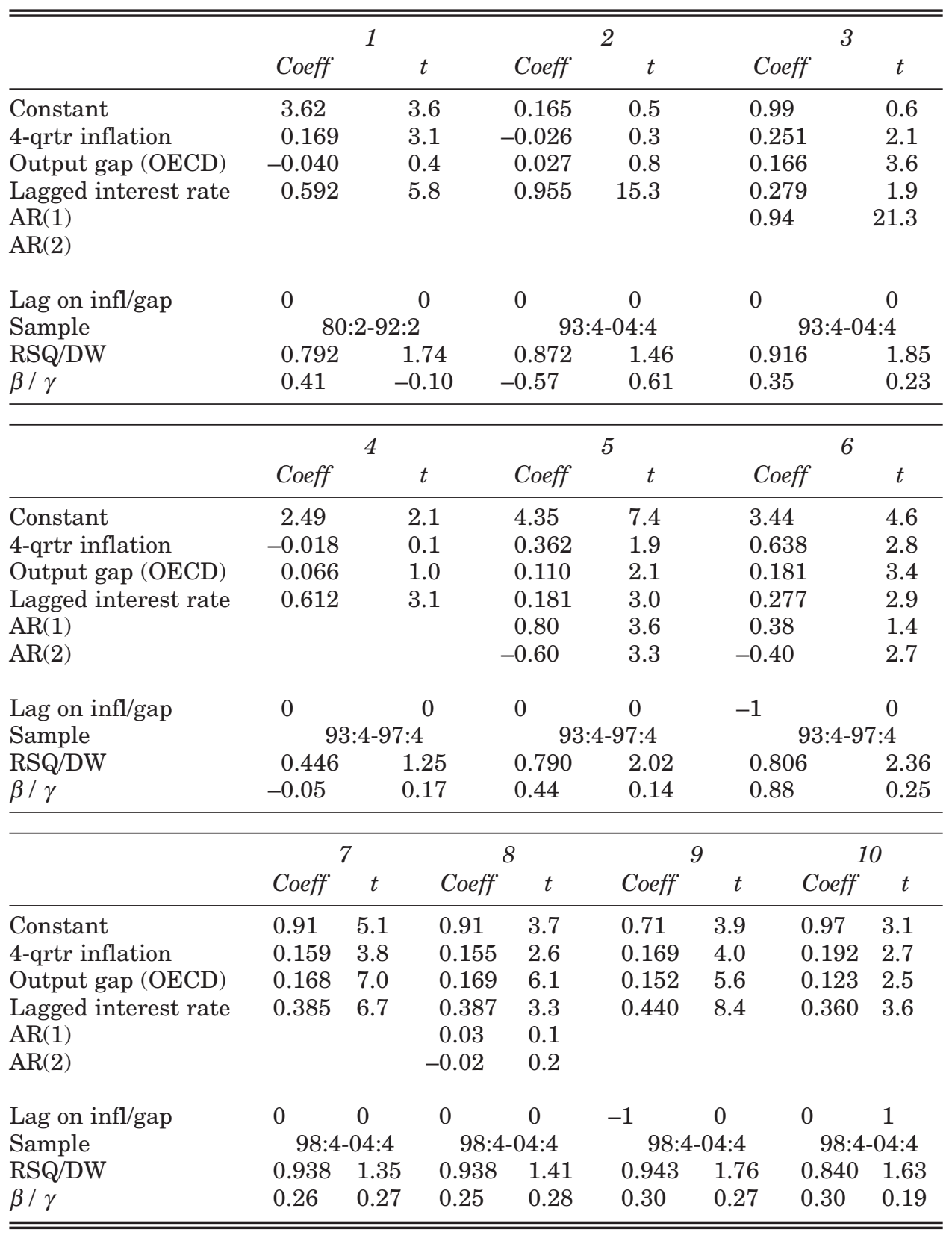

Note: Data from OECD Economic Outlook No. 77. Estimation is by ordinary least squares. The entries "Lag on infl/gap" indicate by how many quarters the inflation rate, and the output gap, are lagged. 
Figure 4: Ireland: Real Interest Rates 1983-2004 (deflated by 4-quarter future inflation)

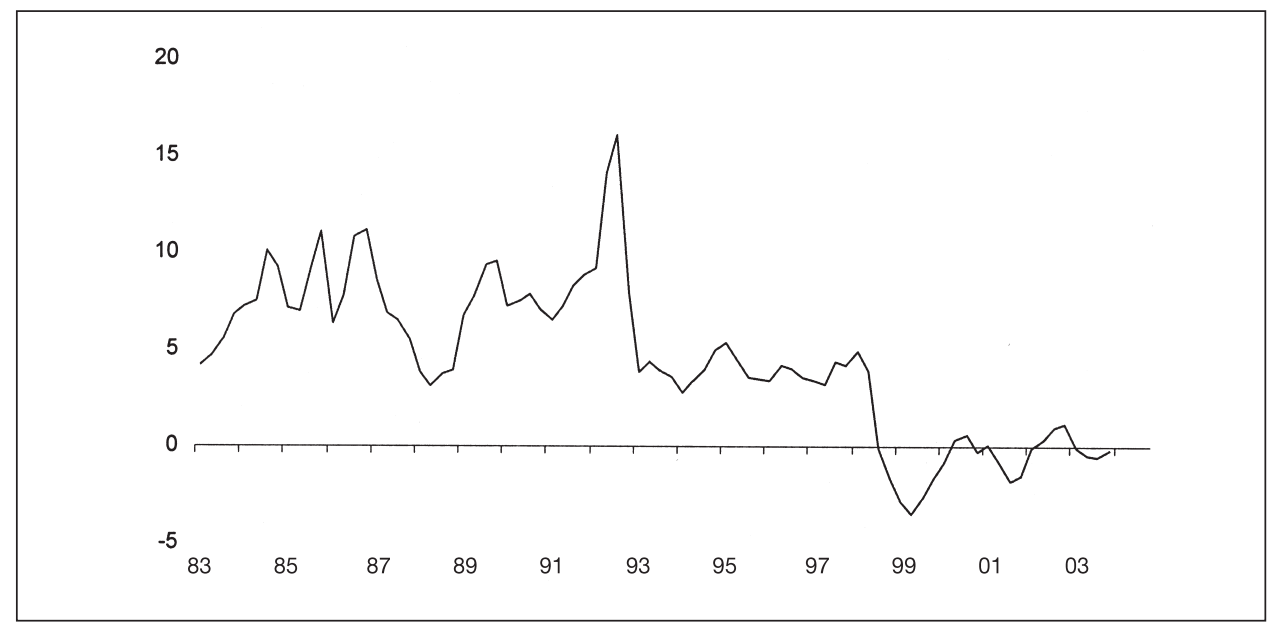

Source: Based on data from Central Bank of Ireland Quarterly Bulletin.

(Regression 3), but the major explanatory power comes from the autoregression, and the estimated values of the coefficients $\beta$ and $\gamma$ are low. The low value of the inflation response $\beta$ in particular (less than 0.4 ) contrasts with the experience for other small countries, as indicated by the panel regression of the same form reported in Honohan and Leddin (2005).

Looking separately at the wide-band ERM period, ${ }^{16}$ inflation and the output gap are once again not significant unless autoregressive terms are included. If we do include autoregressive terms, then inflation and output gap become significant, though again with a small inflation response coefficient, the highest estimated value of $\beta$ being the 0.88 of Regression 6. Once again this contrasts with the results from a panel of small countries.

In the EMU period both inflation and output gap are significant. As we know that Irish macroeconomic conditions have a negligible effect on ECB policy, the significant coefficients here may be considered as induced from the correlation with EMU-wide macroeconomic conditions. For Ireland in EMU this equation can at most be described as a pseudo- or "as if" Taylor rule. Higher Irish inflation and higher Irish output (actually output gap) were actually associated with higher interest rates, even though the Irish data were not driving the policy. Curiously, then, interest rate movements during EMU

${ }^{16}$ Here defined as ending in the last quarter of 1997, reflecting the generally accepted observation that a change in regime emerged during 1998 with the approach of EMU. Note that by estimating the subperiods separately, we allow the intercept of the Taylor equation to differ, so that on average this allows the actual interest rate to have been "right" on average. 
can just as easily - or even more easily - be interpreted as moving in a counterinflationary and countercyclical way on average. However, for the EMU period also, the estimated coefficients are too small to imply a vigorous counterinflationary policy response. While the estimated value of the output response coefficient $\gamma$ at about $0.2-0.3$ is within the range discussed in the literature, the response to inflation, $\beta=0.3$, is well below unity (Regressions 7-10).

Before rushing to the conclusion that neither before nor since the beginning of EMU has monetary policy been sufficiently stabilising, there are some further caveats. For one thing, the inflation surge of $2000-3$ was over by 2004 and at the time of writing inflation is down to about $2 \frac{1}{2}$ per cent. In retrospect the sharp upward jag in policy rates advocated by the Taylor rule (to over 14 per cent by the end of 2000) would surely have been an overreaction. This alerts us to the possibility that the relative weight given to inflation and the output gap in the Taylor rule parameters may be inappropriate for an environment where medium-term inflation stability is guaranteed by the nominal anchor of using an external currency. Perhaps a lower relative inflation sensitivity would be tolerable in such an environment, though this would depend on the implications for future output gap of tolerating a larger interim inflation, and on the elasticity of inflationary expectations. Given that drift in the price level must ultimately be reversed it may be more important to avoid an initial deviation because of the future cost in output gap as inflation readjusts. On the other hand, a lower elasticity of inflation expectations (less danger of an inflation psychology taking grip) may make the reversal of a price blip less costly in output terms.

This section has measured exchange rate shocks to nominal exchange rates in terms of standard deviations of the NEER, and interest rate shocks in terms of their deviations from a Taylor rule. Anyone who thought EMU would bring a substantial improvement on either of these fronts will find little comfort in the data. It would be hard to argue, though, that either source of shock has markedly increased, with the one important exception of the sharp, once-for-all drop in nominal interest rates - to levels well below what the Taylor rule would imply. The effects of this fall are discussed in the next section.

\section{A MODEL OF SHOCK TRANSMISSION EMBODYING MIGRATION AND CONSTRUCTION}

Having considered the role of shocks arising from exogenous interest rate and exchange rate movements, we turn now to look at the market response of 
endogenous variables. Which of the main variables has been the most responsive, and have there been evident changes in the degree to which these responses occur?

In this section we use a simple model to provide an interpretation of the way in which the Irish economy has adapted to EMU-related shocks, with very slow adjustment of wage competitiveness, and overshooting in the property and construction market and in migration. The model is specifically constructed to capture these two specific issues relevant to the Irish economy's response to shocks post-EMU. ${ }^{17}$ Migration needs to be covered because of the exceptionally open nature of Ireland's labour market, and property/ construction because of the size of the interest rate shock and its impact on housing affordability. The model shows how the amplitude of systemic response may change, depending on which of these channels are open.

The full model is set out in the Appendix, together with some simulation plots. Briefly, there are seven equations, modelling wages, the prices of goods and housing, labour demand and migration, the stock of housing and expected price inflation. The wage rate evolves in response to expected inflation and towards an equilibrium relationship between the real wage and employment ratio. Following Gali and Gertler (1999), the price of goods is modelled as a variable mark-up on wage and import price costs, again with a lagged adjustment; the variation in the mark-up depends on expected inflation. The modelling of relative house prices is based on affordability (wages relative to interest costs) and on the stock supply. Residential construction investment continues as long as there is a gap between house prices and the general price level. Employment and output are demand-determined, influenced by international competitiveness, and by house prices (reflecting both a wealth effect and also construction demand), again with a lag. Migration is captured by assuming that the labour force adjusts to close partially the gap between labour demand and supply. ${ }^{18}$ Expected price inflation is very simply modelled as a lagged partial adjustment to actual inflation.

17Duffy, FitzGerald and Kearney (2005) also model the interaction between migration and construction in Ireland; though their goal is to examine longer-term equilibrium, and they use consistent annual data to estimate the equations. Despite significant differences of detail, there is a family resemblance between the two modelling approaches. Our model is focused on short-term dynamic adjustment and in this respect draws on the work of Deroose et al. (2004) whose model is designed for analysis of shocks in the EMU, but who do not model migration or the property market. (Another example of this type of work, with application to Spain, is in Lopez-Salido et al., 2005).

${ }^{18} \mathrm{~A}$ further refinement would be to differentiate between the migration responses of high- and lowskilled workers as in Bergin and Kearney (2004) who assume that only the former migrate and only the latter suffer unemployment, cf. Fitz Gerald and Kearney (2000) and Duffy et al. (2005) . The ESRI modellers also have migration depending on relative wages rather than excess labour market demand. 
As a result of the interaction of lagged adjustments in different markets, models of this type typically predict an adjustment path of prices and quantities that may cycle around the equilibrium, initially overshooting it. 19 Our model is no exception in this respect. Interestingly, for the parameters with which we have simulated the model, the impact of a change in interest rates is most conspicuous at first in house prices, followed by wages, and lastly by consumer prices. The low amplitude of the movement in consumer prices reflects the model's assumption that import prices anchor a large component of consumer prices and that substitution in the product market between imports and local production is high. The initial surge in house prices promotes construction demand and this encourages in-migration, which in turn adds to the demand pressures, though allowing wages to fall back. The potentially protracted nature of this adjustment is evident from the simulations and from the inevitable lags that will be involved in each of the elements. Relative house prices remain high for a long time, even though we have modelled the negative feedback from the accumulating housing stock onto housing prices.

If there were no property market and no migration, the pattern of effects would be quite different. Absent the property market, employment and wages would not rise by so much and the effects would be shorter in duration. Migration has the effect of dampening the wage response, but it increases the duration of the output and employment effect. The simulations reported in the Appendix confirm this intuition. While parametric, the average nominal exchange rate for Ireland against its trading partners is not fixed in the new regime, and this induces shocks to prices and competitiveness that need to be factored-in. In our model, this comes through the import price variable. The consequences for the economy of a rise in import prices are clear enough: competitiveness improves, resulting in an increase in wages and net immigration, as well as higher house prices and construction activity, and higher output generally. The theoretical model thus reveals how, with slow and imperfect macroeconomic adjustment, the initial interest rate shock had the potential to create a sustained construction-led boom with a positive feedback through migration, even despite exchange rate induced losses of competitiveness. In the remaining sections, we present empirical evidence on the evolution of these key variables, showing how actual movements do seem to correspond broadly to the model's predictions, and highlighting in particular the slowness of wage adjustment to losses of international competitiveness.

${ }^{19}$ The literature on how some markets will over-react if others are constrained from clearing has a long pedigree going back at least to Samuelson. In the open economy macro literature, Dornbusch's (1976) overshooting model has been adapted to many different contexts, and its microfoundations strengthened (cf Hau, 2000; Lane, 2001, Obstfeld and Rogoff, 1996). 


\section{ENDOGENOUS RESPONSES IN PRACTICE}

The model of the previous section is, of course, too schematic to capture much of the detail of Ireland's empirical experience. Yet when we look at the empirical counterparts of the model's main variables we find important confirming evidence of the mechanisms described. In particular, we note (following the very large initial fall in interest rates, concentrated in 1998) a dramatic increase in the relative price of property, a sharp upturn in construction activity, unprecedented immigration, and comparatively little evidence of adjustment in wages. In Section 5.1 we briefly document the first two of these developments, turning to migration in Section 5.2 and to the evolution of international wage competitiveness before and since the start of EMU in Section 5.3.

\subsection{Housing}

The surge in residential property prices has been widely discussed (and subjected to econometric analysis, e.g., Roche (2003)). In a period of widespread property booms worldwide, Ireland's experience still stands out as, on at least some measures, the strongest boom. Figure 5 shows a long time series of residential property prices deflated by the consumer price index; even with this deflation, the exceptional nature of recent house price movements can be clearly seen. A major driving factor has been the fall in nominal and real interest rates, which can be seen either as inverse capitalisation factors, or inverse measures of affordability. The fall in nominal interest rates was most pronounced in 1998, the year of most rapid house price increase.

In addition to the price increase, there has been a surge in construction activity, just as predicted by the model. Even relying on data in the Labour Force Survey (ILO basis), the percentage of workers reported in the building sector has jumped from between 6 and 7 per cent, where it stood from 1990 to 1997 , to over 11 per cent by 2004. Increased use of contract workers may mean that the latter figure is understated. Indeed, the increased reliance of the economy on the construction sector has become one of the most distinctive aspects of the economic expansion as it has matured since the effects of EMU began to have an impact. An important aspect of euro membership for the construction sector is that, in contrast to the narrow-band ERM period when the authorities routinely increased rates to defend an overvalued exchange rate peg, real interest rates are no longer positively correlated with the real exchange rate. As a consequence, the construction sector is more insulated than before from external competitiveness shocks.

Whereas exchange rate and inflation expectations have been stabilised by EMU, the potential of destabilising expectations about the relative price of 
housing/property markets still remains, and indeed this sector may increasingly have become the focus of such destabilising expectations.

Figure 5: New House Prices as a Multiple of CPI (Index, 1970=1)

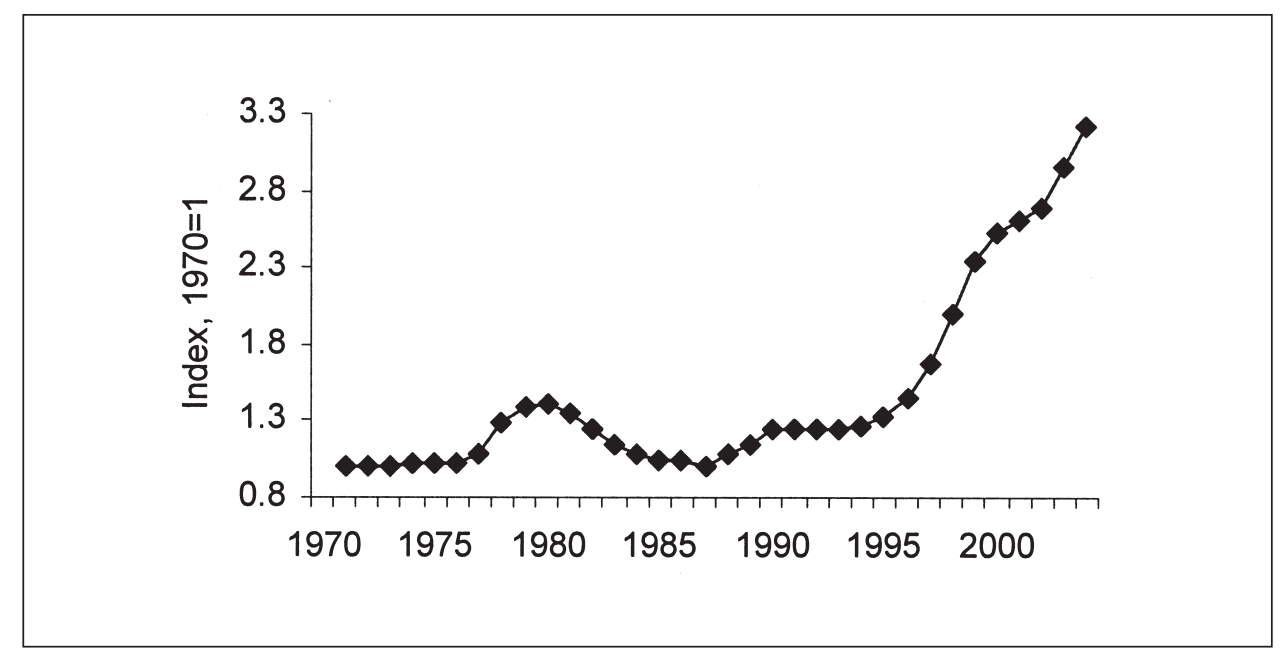

Source: Based on Department of the Environment Housing Statistics Bulletin.

\subsection{Migration}

The relatively modest response of real wages (discussed in 5.3 below) to the initial favourable shocks likely reflects the sizeable migration flows that have occurred. ${ }^{20}$ Inward migration in each of the years 2000-2004 was between $1 / 2$ and 1 per cent of population, and exceeded that for any other year on record (Figure 6). And these have also been the years in which the Irish unemployment rate has fallen below that of the UK for the first time. The surge in migration is very striking: it appears that the labour market has adjusted through quantity movements and not only through prices. But it is not evident from the data that this reflects an autonomous surge in migration behaviour. To be sure, there are novel elements in recent migration flows, but the point here is that much of the additional inflows can be explained purely in terms of an endogenous adjustment of the labour market. For instance,

\footnotetext{
${ }^{20}$ Reflecting the openness of the Irish labour market, some relationships observed in other countries have not been present in the Irish data, whether before or since the start of EMU. Specifically, Irish unemployment does not appear to be closely and reliably related to wage inflation over the period (Phillips Curve, cf. Curtis and Fitz Gerald, 1996; Walsh, 2000). Nor does Irish unemployment correlate well on a short-term (e.g. quarterly) basis with GNP growth (Okun's law), though Walsh (2004) has pointed out that, over a long annual time series period (1961-2000), a significant correlation is obtained.
} 
Figure 7 plots net immigration against the Ireland-UK unemployment differential and shows that recent observations (the six at the upper left) are close to the a regression line drawn for data from the previous four decades (cf. Honohan and Walsh, 2002).

Figure 6: Net Migration in Thousands, 1950-2004

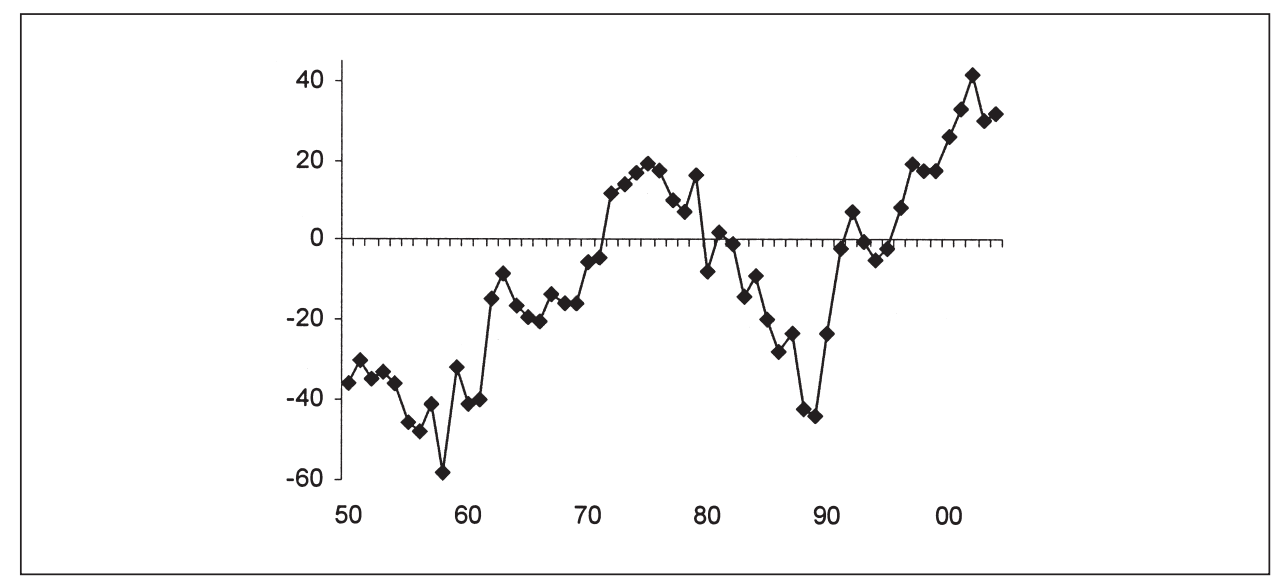

Source: Economic and Social Research Institute Database of Economic Time Series Version NIE03, 2005.

Figure 7: Migration and Unemployment Differentials.

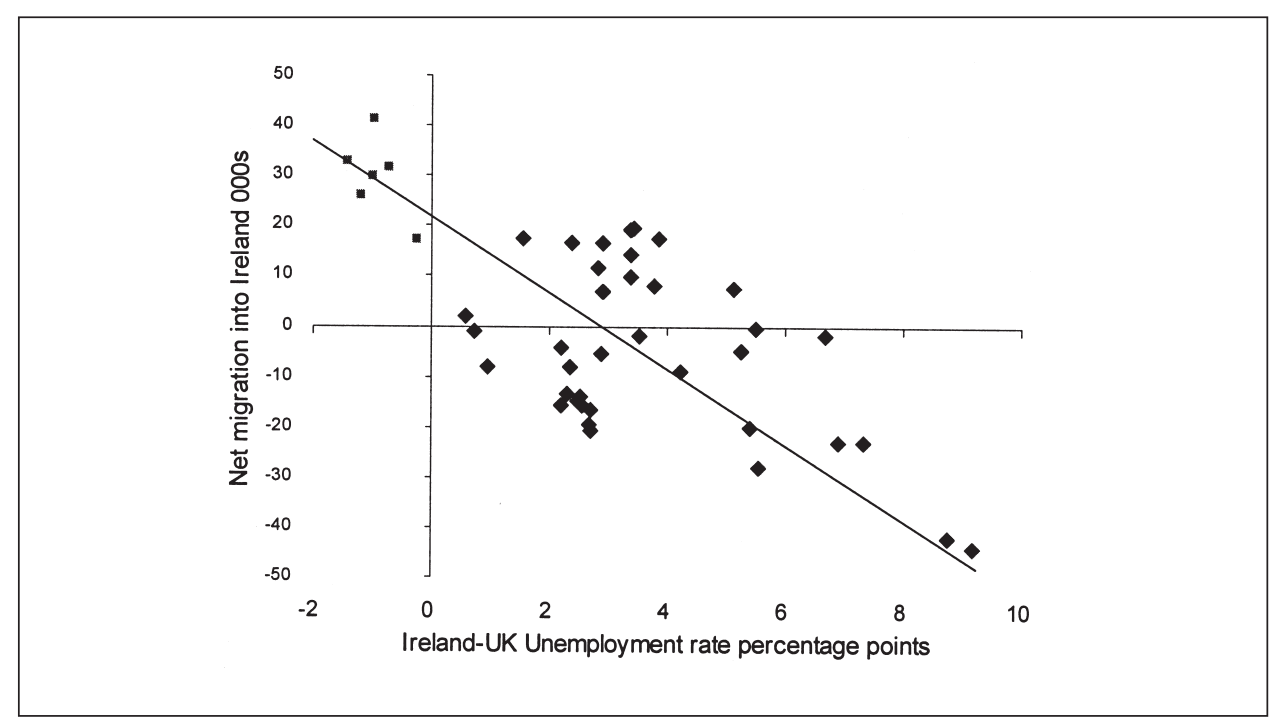

Source: Economic and Social Research Institute Database of Economic Time Series Version NIE03, 2005.

EMU observations marked with square box. 


\subsection{Wage Competitiveness}

Wage competitiveness is clearly the key relative price for macroeconomic purposes. In this subsection we briefly describe recent trends in international wage relatives for Ireland. We find no indication that wage competitiveness is a stable, self-correcting process. Three distinct elements contribute to shortrun fluctuations in wage competitiveness: Irish wage rates, foreign wage rates and exchange rates. ${ }^{21}$ The dynamics of each are distinct. Foreign wage movements can be regarded as exogenous to the Irish economy. Exchange rates are now also exogenous (as discussed above), but before EMU, the DM peg was adjusted from time-to-time in a way which did respond to Irish macroeconomic conditions (Honohan, 1993). Now it is only the nominal wages that can adjust and the speed of adjustment of wage competitiveness to shocks therefore indirectly measures the speed of nominal wage adjustment to a loss of wage competitiveness. Irish wages are themselves subject to a series of bargaining procedures, at centralised national and decentralised levels (Walsh, 2004).

It is well understood that comparisons based on unit labour costs are inappropriate in any data including aggregate manufacturing in Ireland because of the distortions to the measurement of productivity related to low wage share (transfer pricing) sectors (Honohan and Walsh, 2002). Therefore, hourly or weekly wage costs are generally considered the most appropriate basis for tracking short-term changes in the average competitiveness of Irish workers. Unfortunately, official data on aggregate Irish wage competitiveness (measured against trading partners) have, over the years, been remarkably thin and problematic, partly due to the weakness of high-frequency aggregate wage rate data. ${ }^{22}$ Indeed, the annual series published by the Department of Finance and by the Central Bank of Ireland diverge inexplicably at some points (especially at 1985-6 and again in 1996-7) and, since the trade weights for both have never been published, it has not been possible to pin down the reason for the discrepancy.

Figure 8 shows the evolution of the wage competitiveness indexes from the two sources. Regardless of the differences, it is clear from both series that an upward trend (loss of competitiveness) over the previous ten years was interrupted in the mid-1980s for at least a decade. This must have contributed

${ }^{21}$ Of course productivity and quality issues are also crucial, but we leave those in the background for this discussion. For one thing, in Ireland, aggregate measured average labour productivity in manufacturing moves sharply depending on changes in the relative output of low wage-share sectors such as pharmaceuticals, IT equipment and software-related manufactures, without these shifts necessarily reflecting any change in marginal labour productivity.

${ }^{22}$ Even for changes; the question of levels is even more difficult, see Fitz Gerald (2005), who stresses the importance of disaggregating wage changes in Ireland in the past decade as between low-skill and high-skill. 
Figure 8: Aggregate Index of Wage Competitiveness vs. Main Trading Partners:

\section{Two Sources}

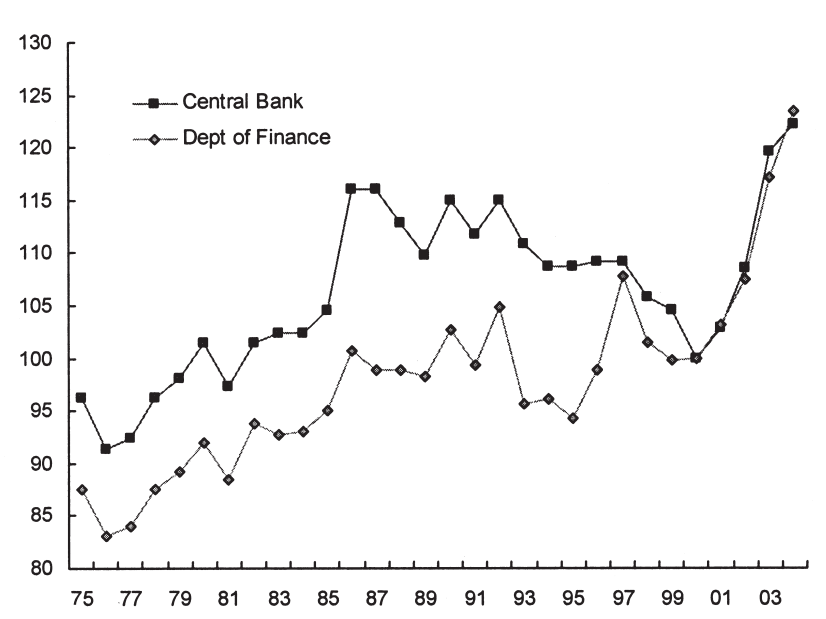

Source: Central Bank of Ireland and Department of Finance. The latter ends in 2001, but is continued by using the same source's figures for UK, US and Germany, weighted $0.19,0.25$ and 0.56 respectively.

strongly to the employment surge of the Celtic Tiger period. (Honohan-Walsh, 2002). Since 2000, however, competitiveness has been lost rather severely.

There is no evidence here of a self-correcting process. For one thing, existence of a unit root cannot be rejected for this data (not surprising for such a short data series). Alternatively, if we assume a common quadratic time trend through the whole period, and estimate a simple autoregressive adjustment process, the results suggest that the adjustment process did exist before 1998, but not since. Specifically, estimating

$$
\Delta w=\lambda(1-\theta D)\left(\alpha_{0}-\alpha_{1} T+\alpha_{2} T^{2}-w_{-1}\right),
$$

where $D$ is an EMU dummy, we obtain $\lambda=0.648(t=2.9) ; \theta=1.32(t=6.5)$, with an R-squared of 0.365 and a Durbin-Watson statistic of 1.88 , for the maximal sample period 1976-2004. The estimated coefficient $\theta$ is greater than unity (and significantly greater than 0.9 ) implies that at least 90 per cent of the adjustment parameter is eroded in the EMU period.

Of course, rising wages, if sustainable, are a good thing, and the present discussion cannot claim to have proved that the sharp upward trend in wages was greater than could be supported by underlying productivity growth (a 
topic which goes beyond the scope of this paper). However the indications, both from visual inspection of the runaway trend, and from simple regression models, is of an adjustment process for wage competitiveness which has lost all traction in these early years of EMU. Absent continued lucky breaks in other dimensions, this is something which will have to change if unpleasant costs are not to be incurred.

\section{CONCLUDING REMARKS}

We began with two questions: are exogenous shocks to the Irish economy larger in EMU and how have the economy's endogenous responses to shocks changed as a result of the regime change? Our conclusion on shocks is that these have not on balance increased by much. There may have been a slight increase in exchange rate volatility. At first sight, short-run effective exchange rate index volatility seems, if anything, to fall during EMU, but closer inspection shows that this is because of the contribution of corrective realignments in the earlier period. Furthermore, the amplitude of the lowfrequency oscillation during the EMU period is higher than was normal before.

The interest rate story also suggests little systematic increase in the level of shocks. Interest rates have not been appropriate to local conditions during EMU, but that was also true for different reasons in the previous exchange rate regimes. We have assessed shocks here by comparing actual interest rates to those which would be generated by a Taylor rule for Ireland. By this standard, interest rates were much too high on average in the ERM period, reflecting agency costs (e.g., the market's fear of an inflationary strategy to solve the problem of high government debt, and its fear that the authorities would pursue an overly devaluationist response to sterling weakness). While there is a long-term benefit to Ireland from the removal of the risk premium that kept interest rates so high in the ERM period, the fall in interest rates has, in the early years of EMU, pushed them below where they should have been for stabilisation purposes according to the Taylor criterion.

Turning from the average level of interest rates to their responsiveness to output gaps and inflation, the ERM period also showed a lack of monetary policy response. Curiously, although interest rates in EMU are not set in response to Irish conditions, the data fit a pseudo-Taylor rule with significant responses to inflation and output gaps. This relationship is presumably induced by the correlation of Irish conditions in the sample period with the EMU-wide factors driving ECB policy. To what extent this correlation is fortuitous, and to what extent structural, is not known. Anyway, the size of the 
response of the pseudo-Taylor rule to inflation is too small (about 0.3) to be sufficiently stabilising in itself.

As to the adjustment of the remainder of the economy, we have stressed the substantial role of the housing market both in prices and in activity. In particular, the initial fall in real interest rates had its most dramatic effect on the property market and especially on residential property prices. As predicted by our simple model, this price effect was transmitted to activity, with the result that the strong aggregate output performance (which has both encouraged and been fed by migration flows) has been increasingly construction-led largely explaining the resilience of economic activity into 2005. Adjustment mechanisms in the labour market seem to have been weak. There is evidence that international wage competitiveness was maintained through an adjustment process around a time trend in the ERM period. But since EMU began, there is no sign of the adjustment mechanism persisting. Indeed, the lack of responsiveness of competitiveness indicators to weakening employment conditions is striking. Instead of wage-price responses, migration flows have continued to represent the major form of labour market adjustment.

The loss of wage competitiveness since the start of EMU has been quite sharp. Against the US, the loss has averaged 3.3 per cent per annum - with earlier gains partly offsetting a more dramatic fall since 2002; against Germany, the loss has averaged 2.1 per cent per annum. The sustainability of such losses must be doubted. Despite the loss of competitiveness, exports have continued to surge, growing by 11.9 per cent in 2004 . However, these data undoubtedly contain a certain amount of momentum reflecting earlier capital formation. Calculations in European Commission (2005) showing that Ireland lost export market share in each sector in recent years, but benefited from its concentration in sectors whose world market was growing, are particularly worrying in this context. The fall in interest rates has unleashed a long-lived property price and construction-led boom which, interacting with longstanding migration forces in a manner modelled by our theoretical model, explains why losses of wage competitiveness have not yet been followed by a downturn in employment as has been feared for several years now (cf. Bergin et al. 2003; Leddin, 2001). As this positive force finally abates, the absence of effective wage adjustment mechanisms suggests that the prospect of a lengthy period of labour market weakness cannot be ruled out. 


\section{REFERENCES}

ADALID, RAMÓN, GÜNTER COENEN, PETER MCADAM and STEFANO SIVIERO, 2005. "The Performance and Robustness of Interest-Rate Rules in Models of the Euro Area", International Journal of Central Banking , Vol. 1, pp. 95-132.

BAKER, TERRY, JOHN FITZ GERALD and PATRICK HONOHAN (eds.), 1996. Economic Implications for Ireland of EMU, Policy Research Paper No. 28, Dublin: The Economic and Social Research Institute.

BERGIN, ADELE, JOHN CULLEN, DAVID DUFFY, JOHN FITZ GERALD, IDE KEARNEY and DANIEL MCCOY, 2003. Medium Term Review 2003-2010, No. 9, Dublin: The Economic and Social Research Institute.

BERGIN, ADELE and IDE KEARNEY, 2004. "Human Capital, the Labour Market and Productivity Growth in Ireland", Dublin: The Economic and Social Research Institute Working Paper 158.

CHARI, V. V., PATRICK J. KEHOE and ELLEN R. MCGRATTAN, 2000. "Sticky Price Models of the Business Cycle: Can the Contract Multiplier Solve the Persistence Problem?" Econometrica, Vol. 68, No. 5, pp. 1151-1179.

CHARI, V. V., PATRICK J. KEHOE AND ELLEN R. MCGRATTAN, 2002. "Can Sticky Price Models Generate Volatile and Persistent Real Exchange Rates?" Review of Economic Studies, Vol. 69, No. 3, pp. 533-563.

CURTIS, JOHN and JOHN FITZ GERALD, 1996. "Real Wage Convergence in an Open Labour Market", The Economic and Social Review, Vol. 27, No. 4, pp. 321-340.

DEROOSE, SERVAAS, SVEN LANGEDIJK and WERNER ROEGER, 2004. "Reviewing Adjustment Dynamics in EMU: From Overheating to Overcooling", European Economy Economic Papers. No. 198. European Commission.

DUFFY, DAVID, JOHN FITZ GERALD and IDE KEARNEY, 2005. "Rising House Prices in an Open Labour Market", The Economic and Social Review, Vol. 36, No. 3, pp. 251-273.

DUPOR, BILL and TIMOTHY CONLEY, 2004. "The Fed Response to Equity Prices and Inflation", American Economic Review, Vol. 94, No. 2, pp. 24-28.

EUROPEAN COMMISSION (DG EFA), 2005. "The Export Performance of the Euro Area”, Quarterly Report on the Euro Area, Vol. 4, No. 1, pp. 32-34.

FAUST, JON, JOHN ROGERS and JONATHAN WRIGHT, 2001. "An Empirical Comparison of Bundesbank and ECB Monetary Policy Rules”, Washington: Board of Governors of the Federal Reserve System International Finance Discussion Papers Number 705.

FITZ GERALD, JOHN and IDE KEARNEY, 2000. "Convergence in Living Standards in Ireland: The Role of the New Economy”, ESRI Working Paper 134, Dublin: The Economic and Social Research Institute.

FITZ GERALD, JOHN, 2001. "Managing an Economy under EMU: The Case of Ireland", The World Economy, Vol. 24, No.10, pp.1353-1371.

FITZ GERALD, JOHN, 2005. "Lessons from 20 Years of Cohesion", Dublin: The Economic and Social Research Institute, mimeo.

FLOOD, ROBERT P. and ANDREW K. ROSE, 1995. "Fixing Exchange Rates: A Virtual Quest for Fundamentals", Journal of Monetary Economics, Vol. 36, No. 1, pp. 3-37.

GALI, JORDI and MARK GERTLER, 1999. "Inflation Dynamics: A Structural Econometric Analysis”, Journal of Monetary Economics, Vol. 44, No. 2, pp. 195-222. 
HAU, HARALD, 2000. "Exchange Rate Determination: the Role of Factor Price Rigidities and Nontradables”, Journal of International Economics, Vol. 50, No. 2, pp. 421-448.

HONOHAN, PATRICK, 1993. An Examination of Irish Currency Policy, Policy Research Series No. 18, Dublin: The Economic and Social Research Institute.HONOHAN, PATRICK and CHARLES CONROY, 1994. "Sterling Movements and Irish Pound Interest Rates", The Economic and Social Review, Vol. 25, No. 3, pp. 201-220.

HONOHAN, PATRICK and BRENDAN M. WALSH, 2002. "Catching Up with the Leaders: The Irish Hare” Brookings Papers on Economic Activity 2002, No. 1, pp. 1-78.

HONOHAN, PATRICK and PHILIP R. LANE, 2003. "Divergent Inflation Rates in EMU”, Economic Policy, Vol. 18, No. 37, pp. 357-394.

HONOHAN, PATRICK and PHILIP R. LANE, 2004. "Exchange Rates and Inflation under EMU: An Update", Centre for Economic Policy Research Discussion Paper 4583, August.

HONOHAN, PATRICK and ANTHONY J. LEDDIN, 2005. "Ireland in EMU: More Shocks, Less Insulation?” Dublin: Trinity College, Institute for International Integration Studies Discussion Paper 96.

KAMINSKY, GRACIELA L., CARMEN M. REINHART and CARLOS A. VEGH, 2004. "When It Rains, It Pours: Procyclical Capital Flows and Macroeconomic Policies," NBER Working Papers 10780. (Also in NBER Macroeconomics Annual 2004.)

KUTTNER, KENNETH N., 2004. "The Role of Policy Rules in Inflation Targeting", Federal Reserve Bank of St. Louis Review, Vol. 86, No. 4, pp. 89-111.

LANE, PHILIP R., 2001. "The New Open Economy Macroeconomics: A Survey", Journal of International Economics., Vol. 54, No. 2, pp. 235-266.

LANE, PHILIP R., 2003. "The Cyclical Behaviour of Fiscal Policy: Evidence from the OECD”, Journal of Public Economics, Vol. 87, 12, pp. 2661-2675.

LANE, PHILIP R., 2004. "Assessing Ireland's Price and Wage Competitiveness", Forfas, mimeo. (http://www.forfas.ie/ncc/pdfs/ncc_discussion_ireland_price_and_ wage_competitiveness_0407.pdf)

LEDDIN, ANTHONY J., 2001. "Economic Adjustment in European Monetary Union: The Irish Experience", Quarterly Economic Commentary, Dublin: The Economic and Social Research Institute, October.

LEDDIN, ANTHONY J., 2004. "Economic Adjustment in the Eurozone: The Irish Experience”, FÁS Labour Market Review, November.

LEDDIN, ANTHONY J. and BRENDAN M. WALSH, 2003. The Macroeconomy of the Eurozone: An Irish Perspective, Dublin: Gill and Macmillan.

LÓPEZ-SALIDO, J. DAVID, FERNANDO RESTOY and JAVIER VALLÉS, 2005. "Inflation Differentials In EMU: The Spanish Case", Banco de España Working Paper 0514.

OBSTFELD, MAURICE and KENNETH ROGOFF, 1996. Foundations of International Macroeconomics, Cambridge, Mass.: The MIT Press.

ROCHE, MAURICE J., 2003. “Will There Be a Crash in Irish House Prices?” Quarterly Economic Commentary, Dublin: The Economic and Social Research Institute, Winter, pp. 57-72.

ROSE, ANDREW and ROBERT FLOOD, 1995. "Fixing Exchange Rates: A Virtual Quest for Fundamentals”, Journal of Monetary Economics, Vol. 36, No.1, pp. 3-37. 
WALSH, BRENDAN M., 1970. "Econometric Macro-Model Building in the Irish Context", ESRI Quarterly Economic Commentary, Dublin: The Economic and Social Research Institute, June, pp. 16-26.

WALSH, BRENDAN M., 1974. "Expectations, Information and Migration: Specifying an Econometric Model of Irish Migration to Britain", Journal of Regional Science, Vol. 14, pp. 107-120.

WALSH, BRENDAN M., 1984. "Ireland in the European Monetary System: A Progress Report on Four Years of Membership" in P. J. Drudy and D. McAleese (eds.), Ireland in the EEC, Cambridge: Cambridge University Press.

WALSH, BRENDAN M., 1993. "Credibility, Interest Rates and the ERM: the Irish Experience, 1986-92”, Oxford Bulletin of Economics and Statistics, Vol. 55, No. 4, pp. 439-452.

WALSH, BRENDAN M., 2000. "Cyclical and Structural Influences on Irish Unemployment”, Oxford Economic Papers, Vol. 12, No. 3, pp. 119-145.

WALSH, BRENDAN M., 2004. "The Transformation of the Irish Labour Market, 19802003", University College Dublin Working Paper 04-12. Presidential Address to the Statistical and Social Inquiry Society of Ireland. 


\section{APPENDIX: A SIMPLE DYNAMIC MODEL}

A simple algebraic model of price and wage dynamics, such as has recently been used to simulate the differential impact of shocks on different euro-zone economies (cf. Deroose et al. 2004), can be adapted ${ }^{23}$ to show the role of the construction industry and migration in an economy such as that of Ireland where these have proved important in the EMU years. Recently, Duffy et al. (2005) have also modelled the interaction between migration and house prices for Ireland, and there are significant similarities in the modelling, albeit their approach has a longer-term perspective in contrast to the current exercise designed to illustrate short-term fluctuations and interaction between the sectors.

Four prices are important: $w$, the nominal wage rate; $p$, the price of goods; $p^{h}$, the price of housing; $p^{*}$, the exogenous price of foreign goods. The level of employment $n$ and the labour force $l$, and the housing stock $h$ are stock variables, the latter two to be taken as slowly-evolving state variables as we will see. All these variables expressed in logs. The inflation rate is written $\pi_{t+1}=p_{t+1}-p_{t}$ and superscript $e$ denotes the expectation (at the previous period - i.e. $p_{t+1}{ }_{t+1}$ is the expectation at time $t$ of the price at time $\left.t+1\right)$; the nominal interest rate (not logs) is $r$.

The nominal wage rate evolves in response to expected inflation movements towards an equilibrium relationship between the real wage and employment ratio:

$$
w_{t}=w_{t-1}+\alpha_{1}\left(p_{t}^{e}-p_{t-1}\right)+\alpha_{2}\left[\alpha_{3}\left(n_{t-1}-l_{t-1}\right)-\left(w_{t-1}-p_{t-1}\right)\right]
$$

The price of goods is modelled as a variable mark-up on costs: the costs are modelled as a fix-weight average of wages and import prices; the mark-up increases with higher expected inflation (Gali-Gertler, 1999). Even though the Gali-Gertler story already embodies staggered price-setting, we follow Deroose et al., in allowing gradual adjustment to the modelled mark-up.

$$
p_{i}=v p_{t-1}+(1-v)\left[\lambda_{1} w_{t}+\left(1-\lambda_{1}\right) p_{t}^{m}+\lambda_{2}\left(p_{t}^{e}-p_{\mathrm{t}-1}\right)\right]
$$

\footnotetext{
${ }^{23}$ The main differences with Deroose et al. are as follows: (i) whereas they treat interest rate movements as having a generalised demand effect, we model the construction sector separately thereby allowing a distinct interest rate effect, and revealing housing price dynamics; (ii) we allow the labour force to evolve in response to real wage differentials; (iii) we include a housing wealth term in lieu of net foreign assets (as we regard the latter as too slow-moving to have interesting short-term dynamics; (iv) we do not include the quadratic inflation term in the price equation.
} 
As a long-lived asset, the fundamental price of housing is often modelled as being determined by the discounted present value of future rentals and terminal resale value. The future resale price is hard for the market participant and for the modeller to determine with any precision, and the degree to which a bubble might also be present in the actual price is widely studied (for the Irish context, see Roche, 2003). Furthermore, myopia, liquidity constraints and transactions costs can make short-term considerations of affordability and user demand equally, or more relevant to short-term price determination, as well as being easier to model. The major elements of the affordability calculation are aggregate wage income and the real interest rate (during high inflation, nominal interest rate may be separately relevant). The market-clearing price of housing will be higher, the higher the affordability and the lower the stock of housing; this is the basis of Equation (3) (cf. Duffy et al., 2005). In the present exercise, we do not attempt to include a term capturing expectations of resale value.

$$
p_{t}^{h}=p_{t}+\beta_{1}\left(w_{t}-p_{t}+n_{t}\right)-\beta_{2}\left[r_{t}-\left(p_{t}^{e}-p_{t}\right)\right]-\beta_{3} h_{t-1}
$$

Residential construction investment continues while the relative price of housing is above its equilibrium value. ${ }^{24}$

$$
h_{t}=h_{t-1}+\xi\left(p_{t-1}^{h}-p_{t-1}\right)
$$

Ignoring issues of factor substitution, we will simply assume that employment is proportional to aggregate output, and that the latter is demand determined, influenced by international competitiveness (external demand), and house prices (wealth effect and also construction demand - the parameter from the construction Equation (4) reappears here). Inertial factors are also influential. Government demand $g$ is an additional, potentially endogenous factor, included to flag also the many other exogenous elements which could be added to a model for estimation (raw material costs, productivity changes etc).

$$
n_{\mathrm{t}}=\mu n_{t-1}+(1-\mu)\left[\left(\gamma_{1}+\xi\right)\left(p_{t-1}^{h}-p_{t-1}\right)-\gamma_{2}\left(w_{t}-p_{t}^{m}\right)+\gamma_{3} g\right]
$$

A partial adjustment equation for the labour force is added, effectively modelling migration. (Again we ignore the many other exogenous terms that could be relevant - foreign wage rates, social benefits etc.)

\footnotetext{
${ }^{24}$ Actually, this is more appropriate for the price of a new house on marginal land. Average house prices will include location premia for the land.
} 


$$
l_{t}=l_{t-1}+\zeta\left(n_{t-1}-l_{t-1}\right)
$$

In line with much of the recent literature, the role of rational expectations is suppressed in the modelling of expected price inflation, for simplicity and allowing greater clarity of the mechanisms with which we are chiefly concerned here. Thus we base the calculations on the partial adjustment mechanism, $\pi_{t}^{e}=\pi_{t-1}^{e}+\varphi\left(\pi_{t-1}-\pi_{t-1}^{e}\right)$.

For constant values of the exogenous variables $p^{m}, r$, and $g$, the steadystate equilibrium of this system can be solved to yield:

$$
\begin{aligned}
w_{\infty} & =p_{\infty}=p_{\infty}^{h}=p^{m} ; \\
l_{\infty} & =n_{\infty}=\gamma_{3} g \\
h_{\infty} & =\left[\beta_{1} \gamma_{3} g-\beta_{1} r\right] / \beta_{3}
\end{aligned}
$$

Thus, the long-run labour force and employment is proportional to the exogenous spending variable, the housing stock is also permanently influenced by the interest rate. The nominal variables are homogeneous of degree one in the exogenous import price. (These results reflect the mediumterm perspective in which no government balance sheet constraint is imposed.)

Simulating this model reveals the reinforcing nature of the migration and construction channels on the duration and magnitude of the boom resulting from an initial fall in the nominal interest rate. Figures A1 (a-c) show the simulated timepath of the variables. Time is on the horizontal axis; the vertical axes show deviations from initial equilibrium. The scale and time period is wholly notional - the main interest lies in the overall shape of the simulations. Figures A2 (a-b) show how the time path of the real wage rate and of employment or output vary depending on whether the migration or construction channels are suppressed $(\zeta=0, \xi=0$, respectively). Here perhaps is the key to extended duration of Ireland's boom through the EMU years, an interpretation which is supported by the very high share of output taken by construction in recent years. Without migration and the construction channel, wage rates and output could have been much lower. 
Figure A1: Simulated Effect of a Sustained Fall in Interest Rates

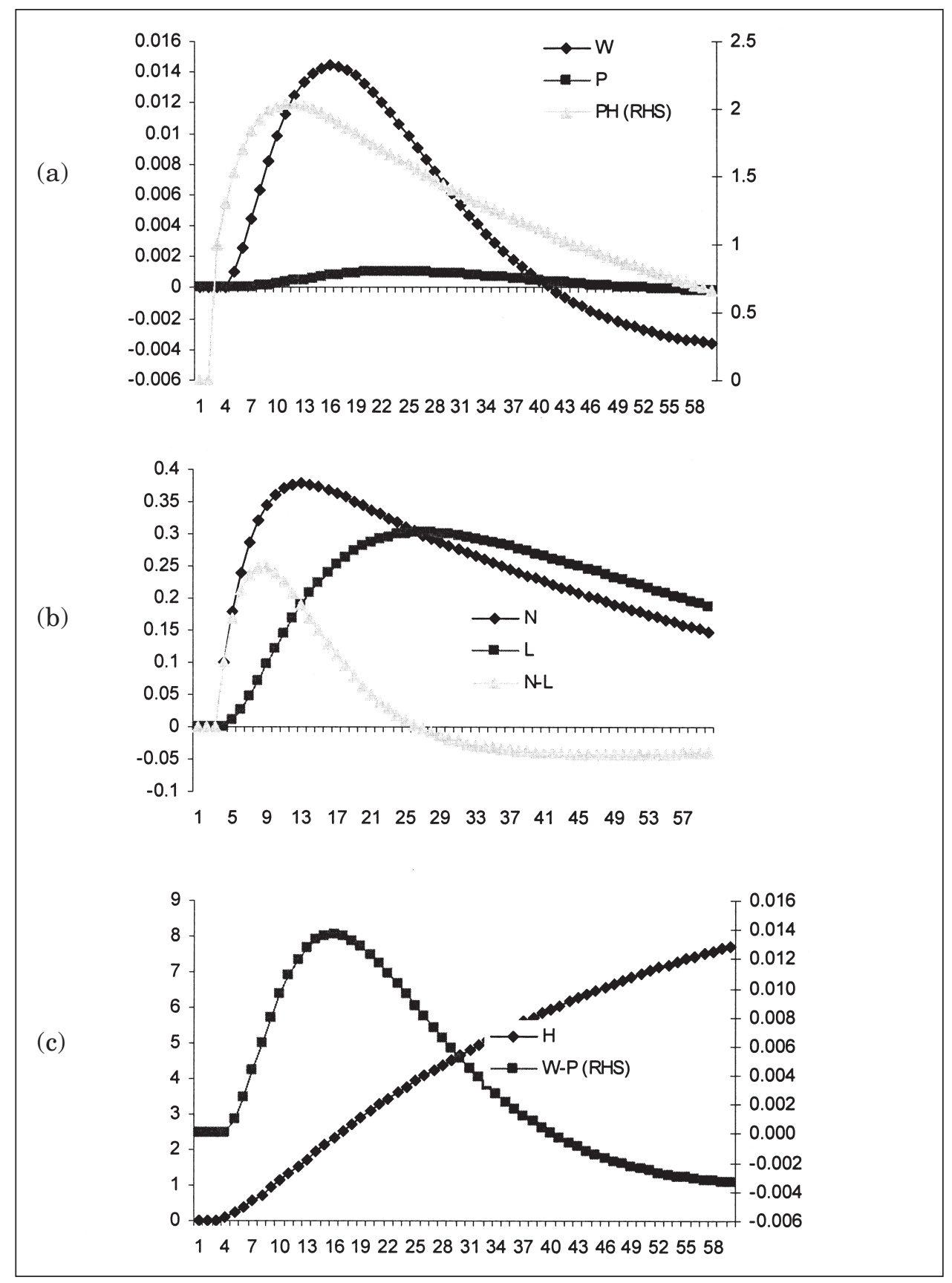


Figure A2: Impact of a Fall in Interest Rates if Migration and Construction Channels not Available

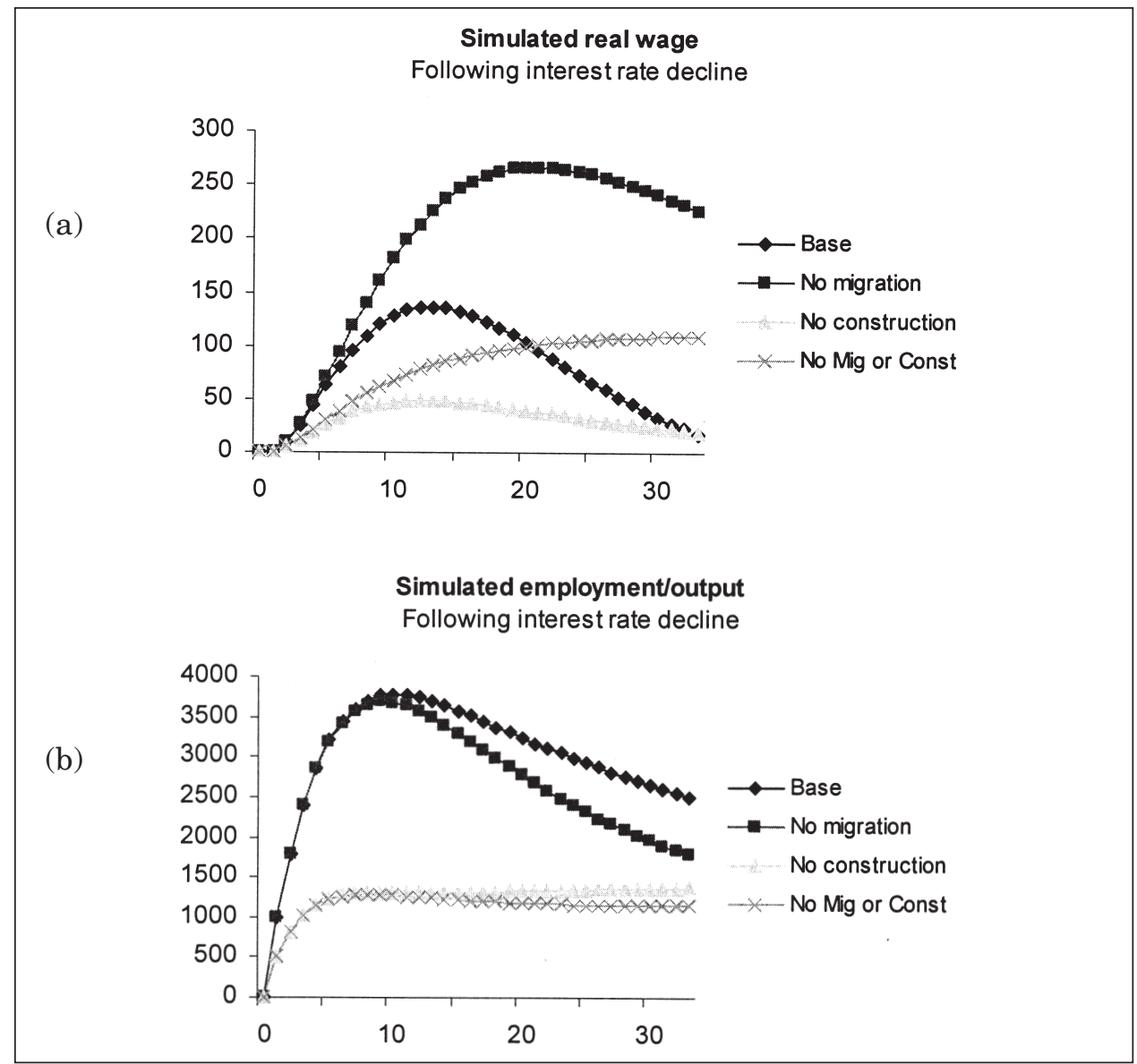

Note: Parameter values: $\alpha_{1}=0.9 ; \alpha_{2}=0.1 ; \alpha_{3}=0.1 ; \beta_{1}=3 ; \beta_{2}=20 ; \beta_{3}=0.1 ; \lambda_{1}=\lambda_{2}=0.1$; $\mu=0.5 ; v=0.9 ; \psi=0.9 ; \zeta=0.1 ; \xi=0.1 ; r=-0.05 ; p^{m}=0.2$. 